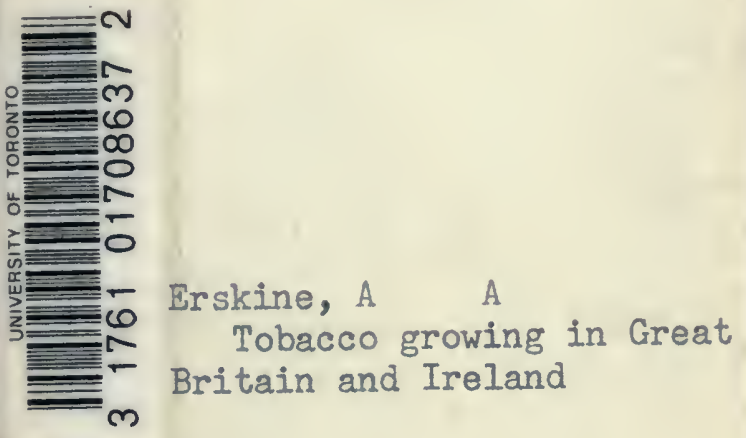

$5 B$

278

GTE? 



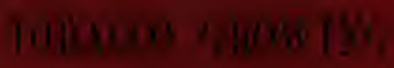

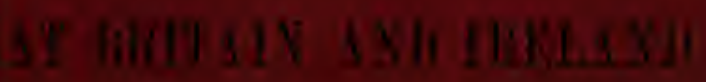

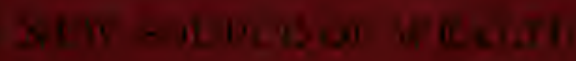

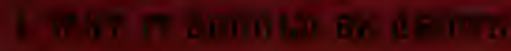

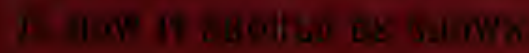

1

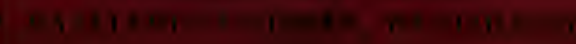




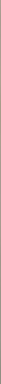





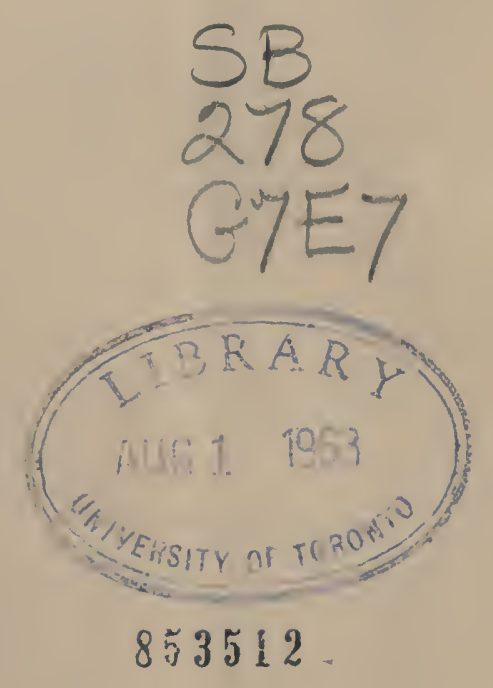




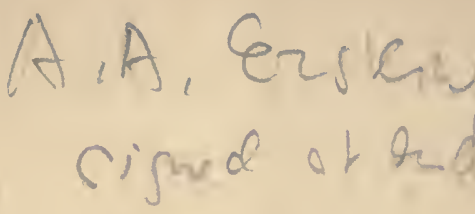

\section{TOBACCO GROWING}

IN

\section{GREAT BRITAIN AND IRELAND.}

I.

WHY IT SHOULD BE GROWN.

"IT was not many years," wrote Blythe, in 1649 , "since the famous city of London petitioned the Parliament of England against two anusancies or offensive commodities, which were likely to come into great use and esteem; and that was Newcastle coal, in regard of their stench, etc., and hops, in regard they would spoyle the taste of drink and endanger the people."

It is now a great many years since the abore was written, and the petition of the famous city of London falls flatly ridiculons on modern ears. We hope to show, in the following pages, that all former reasons, prohibitive of the growth of tobacco in the British Isles, are now equally obsolete and inapplicable, also that the climate 
of this country is well adapted to the cultiration of this plant, and that the present state of agriculture being far from satisfactory, it has become the duty of the Government, and the interest of the pcople, to sce that the old restrictive Acts of Charles II. and George III. be repealed or amended to meet the new conditions which have arisen in our Empire and in the United Kingdom itself.

The public is, at present, in extreme ignorance on the subject of tobacco.

Most people imagine that the weed they so much cherish comes from some tropical island, or from some excecdingly hot State of America, and that no other part of the world is able to supply them with this luxury. Instcad of which, Holland, Hungary, Germany, and Franco send us annnally large supplies of tobacco; and in England, Scotland, and Ireland tobacco was successfully grown before the law stepped in and put an end to the practice.

De Coin, a tobacco planter, observes:- "The people of those colonies are very defective, somehow or somewhere, in their systems of economy, who rely upon importation from an opposite or antipodal part of the world for a costly material, which they might mise within one hundred yards of their own bedrooms." 
Jonathan Carner, in his celebrated treatise on growing tobacco in this country, significantly observes :-

"When the very great profits, arising to the planter, from every acre of tobacco, come to be known (they will appear chimerical if $I$ inform my readers to what they amount), I doubt not but that tobacco will be considered as the most valuable branch of agriculture which can be attended to."

But before the public, or at least that ignorant majority to whom allusion has been madc, can be taught to consider the above vicw of the case as applicable to England and Ireland, they must be led step by step, from country to country, and from evidence to proof, in order to realise that tobacco does flourish abundantly in Europe, has flourished in the British Isles, and will flourish again, as far as climate and soil are concerned-these two essentials being, perhaps, better suited to its safe development in temperate than in tropical countries.

To quote Brodigan, who grew tobacco in Ireland more than fifty years ago, and wrote a valuable treatise on the subject, wherein he says, with regard to climate: "It is well known that, as we approacl the tropies, the calamities to which vegetation is subject increase. In our 
uniform climate, exempt from those derastating hurricanes, hailstorms, inundations, and periodical gales, which in a few moments destroy the hopes of the planter," etc., he continues to enumerate the diseases and injuries to which the plant is subject in Virginia, i.e., "wormholes, ripeshot or sunburnt, moonburnt, houseburnt, stunted by growth, torn by storms of hail or wind, injured or killed by frost," while in the British Isles, except for an occasional gale or untimely frost, we are almost exempt from those dangers.

Dutonr, in his Nouveau Cour d'Agriculture. says :

"To prevent the nse of this plant, which Providence has suited to the growth of almost every climate, is to reject the bounty of Nature, and to oppress the forlorn and the poer." And when it is further shown, not only in what countries of America and Europe tobacco thrives and gives rise to great industries, but also that it has thriven in this country and promised to secure equal advantages to us, it is to be hoped all prejudice will be overcome, whether produced by greed of gain in the Government on one hand, or the difficulty of leaving a groove, and the fear of novelty and experiment, on the other.

What we demand is a change in the laws 
which were enacted under Charles II. and George III., forbidding the home growth of tobacco.

The Act of Charles II. was passed when, according to Guthrie, Virginia and Maryland jointly shipped to England an annnal average of 96,000 hogsheads, valued at $£ 768,000$. Of this, 13,500 hogsheads we re-exported to the other countries of Enrope, the total value returning to England, while our colonies were benefited and their trade encouraged.

Now that these colonies no longer belong to England, the original reason for the restrictive laws has vanished, as the annual thousands which, before their independence, passed and repassed between them and us, in the cultivation and preparation of this article, now leave England once for all, to pass into the hands and encourage the trade of foreigners. The sum which actually left us in payment for foreign tobacco in the year 1884 amounted to $£ 3,715,812$, the quantity imported being $56,695,74: 3 \mathrm{lbs}$.

The second great reason for maintaining the prohibitive Acts was the extraordinary revenue to be derived by the Government by the easy method of forbidding home production and leavily taxing the foreign. In 1831, when the last Act respecting tobacco was passed, the 
difficnlty of adjusting the revenue was one of the chief reasons given by the Select Committee for continuing the restrictive policy. This is a deep and important subject certainly, involving much difficulty, but equally, certainly, not involving an insurmountable obstacle.

How, it may be asked, is the matter of revenue managed in the continental countries, where tobacco forms a staple commodity?

In Austria, for instance, tobacco is a State monopoly; the State fixes its own profits, and all tobacco is carried to depôts, where regular Commissioners give the planters a fair market price.

In Belgium the plant is taxed, as it stands, at two centimes per plant, unhealthy plants being exempted from taxation, thus raising a tax of about $£ 13$ per acre, reckoning 16,000 plants to an acre, as the Belgians do.

These methods answer to the satisfaction of the Government authorities; and, at all events, the foreign systems should be officially inquired into before fiscal difficulties be considered insurmountable in England.

The produce of Customs duties on tobaceo in France in 1885 amounted to $\$ 15,600,750$; while in England, in consequence of our extraordinary partiality for and care of foreign trade, our net 
produce of Customs duties on tobacco amounted to only $£ 9,277,058$. Why this enormous difference, except that our restrictive system does not attain the desired ends, and that France protects her home produce and heavily taxes foreign? It is true France is a larger country than the kingdoms of Great Britain and Ireland; but it is equally true that our population is, in proportion, very much greater than hers, amounting in 1883 to $35,250,000$, while in France the population was $37,320,000$.

Lord Harris, in introducing the subject of tobacco before the House of Lords on the 29th March, suggests three means of raising the necessary tax. He says : "1st. There might be an acreable tax; but there would be some difficulty in this plan, because, unless a system of guarantees were established, it would be doubtful whether men eould be found to put down so large a sum as would be required; 2ndly. Comes the exeise duty on the cured tobacco; this is undoubtedly the fairest plan, and will, I hope, prove feasible; lastly, the cess might be levied, as in Belgium, at so much per growing plant." His Lordship further stated that he proposed a tax equivalent to the present $3 s .6 d$. per poand to be placed on the home growth. Here, however, we must beg to differ very emphatically. 
If English tobacco were taxed to the same extent as the produco of America, the competition would prove an unoqual strifo against experionce, prejudice, and so forth; and. Euglish tobacco would certainly be a failure. By placing an increased tax of say from $4 s .6 d$. to $6 s .6 d$. on foreign tobacco, and a lesser tax of say $2 s$. or 2s. $6 d$. on the produce of this country, we should be placed on a fair footing and be giren the slight advantago and encouragement which at all ovents during the first fow years the new industry would require, till the public taste had been suited, a market assured, and tho necossary experience acquired.

On each pound of unmanufactured /tobacco coming into this country we, at present, pay tho Government from $3 s$. $6 d$. to $3 s .10 d$. (according as the leaf contains more or less moisturo) for a production worth from $4 d$. to $1 s .6 d$. on its native soil; in England wo pay from $4 s$. to $12 s$. per pound in consequence.

Supposing the home-grown tobacco to be sold at $3 s .3 d$. per pound, with a local duty of $2 s$, there would still be a handsome profit to the planter and the manufacturer, employment to thousands, and all the money kept in the country.

Then too, in the Continental countries, where 
tobacco is grown, foreign tobacco of a superior quality is imported to mix with the home growth and produce a more approved flavour; this would certainly be the case in England also, and the price of tobacco being greatly reduced, the consumption consequently much increased (as in Germany and other European countries, where, the taxation being low, the consumption is relatively much larger than our own), and a considerable quantity imported as well-the imported, of course, retaining a heavy tax-the Government could be no loser in its revenue, and, by indirect means, would certainly be a gainer by the new régime. On taking into consideration, as Brodigan suggests, the saving of freight, commission, insurance, and shipping. added to the advantage of having the article at hand and readily convertible into money on the spot, we natives of Great Britain and Ireland ought to be able to produce tobacco thirty or forty per cent. cheaper than that which we import flom foreign climes.

"By this means," says Jonathan Carver (1779), alluding to the growth of tobacco at home, "the revenue, which has been so greatly diminished by the unhappy divisions between Great Britain and the Colonies, will be in a great measure restored. The duties to be col- 
lected for this purpose may either be laid on the plants before they are gathered or during the time of cure, as on the article of malt .... which would probably, at no distant period, amount to as much as was heretofore received on imported tobacco,"-he was wiiting, of course, before the duty on hops was removed.

Three-fourths of the demand for tobacco in this countr'y is for shag or common roll, so that, even if the finer kinds could not be grown here, still a very large proportion of the trade would be kept in our hands; but on this subject Carver again remarks, - and it may be observed that he was a planter himself:-

"The crops that I have reason to believe may be raised in England will greatly exceed in flarour and efficacy any that is imported from the southern colonies: for, though northern climates require far more care and exactness to cultivate and bring tobacco to a proper state of maturity than warmer latitudes, yet this tardiness of growth tends to impregnate the plants with a greater quantity of salts, and consequently of that aromatic flavour for which it is prized, than is to be found in the produce of hotter climes, where it is brought to a state of perfection from the seed in half the time required in colder regions." The following extract is from 'The Daily Tele- 
graph :- "In $1878 \mathrm{Sir}$ Stafford Northcote raised the duty upon unmanufactured leaf from $3 s$. to $3 s .4 d$. per pound, with the result that what are called drinking tobaccos . . . have superseded the older, dryer, and more fragrant growths. The consequence is, that the poor man's pipe, fed by a tobacco more than three-fourths of which are water, retains scarcely any flavour of the nicotian weed. Turning, however, from fiscal considerations to those connected with the depression and distress under which our agriculturists have laboured so long, we may well ask: 'Is there any reason why they shonld not be allowed to grow a plant at home from which their predecessors used to reap such enormous profits?' It is said by experts that no soil and climate in the world are better adapted to grow tobacco of a particular kind than the southern counties of England and the whole of Ireland. The finest leaf for making the cigar wrappers is grown in Connecticut; but American planters pronounce, without hesitation, that it might be grown still better upon the red soils of Devonshire."

The average value, mentioned already as being from $4 d$. to 1s. $6 d$. per pound, does, in some cases of extraordinary fine tobacco, rise to much more; for instance-some tobacco grown in North Carolina fetched $\$ 2 \frac{3}{4}$ per pound in the leaf, and 
the enormous sum of \$ $\$$ per pound was obtained at the Centennial Exhibition for some Virginian tobacco.

From the foregoing statements it will be seen that the political reasons which formerly induced the Government to place a prolibitive duty on home-grown tobacco-i.e., benefiting the English colonies and sccuring a source of revenue, have entirely disappeared-as entirely, we venture to think, as those less political reasons which induced the Popes to inveigh against smoking as irreligious and profane, and which caused the Russian rulers to punish smokcrs with the loss of their noses, the Turks forcing the unfortunate votaries of the pipe to have the said implement thrust up their nostrils--the Persians eren punishing the offence with death; for so infatuated were these Eastern people with the newlyimported luxury, that sooner than forego the pleasure of its indulgence they left their homes and fled to the mountains to smoke in peace.

Equally unreasonable, and equally out of date, appear the motives which prompted our own James I., in slightly less barbaric England, to fulminate his celebrated "Countcrblaste" to tobacco, in which smoking was said to be "a custom loathsome to the eye, hateful to the nose, harmful to the brain, dangerous to the lungs, 
and, in the black, stinking fume thereof, nearest resembling the horrible Stygian smoke of the pit that is bottomless."

When we consider the immense advantage to be derived by the necessary change in the laws, it may well seem astonishing that a decided effort in that direction should be delayed.

As far as the "allotments" or the "small holdings" are concerned, the cultivation of tobacco would be apparently the only means of making such a system a profitable one.

England has, by a series of disappointments, proved that corn-growing, even when undertaken by capitalists-men who have brought science, education, and every modern improvement to bear, is now a ruinous enterprise, and one after another estates and farms are being laid down to grass as the least expensive manner of using the land-meaning, of course, labour minimised and labourers thrown on their own resources, i.e., the parish.

On the other hand, tobacco-growing can be practised and made profitable on exceedingly small areas of land and without the outlay of much capital.

The following table of outlay and returns is furnished by the tobacco-growing farmers in the ricinity of Blandain, a frontier town of Belgium 
(1886). It may be observed that the rent, rates, and taxes in Belgium are exceptionally high, and that the manure is put down at an exorbitant price, owing to the fact of the eultivation of tobacco being carricd on by very small landowners, who cannot afford to procure the manures wholesale.

(A translation of the original document is subjoined at the end.)

\& s. $d$.

Manures • . $17 \quad 9 \quad 4$ per acre.

Labour . . $17 \begin{array}{llll}17 & 9 & 4 & \end{array}$

Rent, rates, taxes . $5 \begin{array}{llll}5 & 6 & 8\end{array}$

\section{$£ 40 \quad 5 \quad 4$}

To this lias to be added a duty of two eentimes a plant, about 16,000 plants being calculated to an acre. An ordinary year yiclds $2,700 \mathrm{lbs}$. an acre, of which 70 per cent. is first quality, and 30 per cent. second and third quality; the first quality selling at $6 \frac{1}{2} d$. per lb., and the seeond and third qualities at about $4 \frac{1}{2} d$. ; tho net profit amounting to about $£ 18$ or $£ 19$ per acre. This calculation does not take into account the enhanced value of suceceding crops, of which it is reekoned that four or five corn-crops ean be taken off the land without extra manning. 
We subjoin Brodigan's calculation, written in 1830 , as it is interesting to compare the two. Brodigan grew a large species of tobacco, so that many fewer plants were grown to an acre.

Outlay for six months per acre:-

\& s. d.

Ploughing, harrowing, hoeing, etc. . $210 \quad 0$

Rent . . . . . . 1100

Labour from planting to curing . 1150

Manure . . . . . 4160

Tithe, et:. . . . . . 036

$£ 20 \quad 4 \quad 6$

The above authority estimated the produce of one acre as 1,500 lbs., but allows that a very rich soil would double that amount. He further makes the following statement:-

"Being limited in ground, I had some early vetches mowed off this land about the middle of June" (speaking of Ireland), "and then prepared for tobacco; after the tobacco had been removed it was sown with wheat, thus realising two crops and placing a third in the samc soil in one year. This is perfectly practicable." Further mention of tobacco as a rotation crop will be made later on.

Let any practical agriculturist compare the 
cost and the receipts of corn-growing with those of tobacco-growing, and the more minutely lie considers the subjeet the more convineed will he be, that, whereas by the former ho has of late years been a loser, by the latter he will be a considerable gainer. Let the eeonomist take the same matter into consideration, and he will find that at the present moment thousands of landowners and farmers are unable to give employment even, during harrest, time, - our one-sided system of unreciprocated free imports is practically doing away with English harvests, and the poor, who used to look forward to the harvest as a time for making a "harvest" of their own, earning a little extra money for the extra expenses of winter, now, in thousands of districts, find the summer their slackest time (in Ireland it is almost universally a timo of greatest idleness and distress), and consequently, that a new industry which gives employment all the summer and autumn months will be an unspeakable boon to the country.

Many objections probably will be raised, on the seore that tobacco will interfere with the more important production of food-crops-and this we admit is an important consideration in a country such as this, where our supplies could easily be ent off-but, in the first place, is there 
any likelihood of the revival of corn crops? 'Since the Governments, following in the footsteps of Cobden, have acted in accordance with the idea that our chief industry was to be manufacturing and not agricultural, and that we were to be the Queen of manufacturing nations-a fallacy, alas! as other countries are far in advance of us now -but since our duties and regulations have been framed in accordance with this view, the English farmer is far too heavily handicapped to venture, with his eyes open, to lay out his capital on crops that will find no market on account of the foreign crops which are not handicapped at all.

Corn growing, then, being a losing industry, is not likely to increase, but rather diminish, now that the farmer has opened his eyes to the fact that his losses are not merely due to bad seasons, but to fiscal causes, apparently equally beyond his powers to avert-so that the cultivation and cure of tobacco could not be fairly considered as a possible deterrent, or in the slightest degree prejudicial to food production, whereas it will and must be productive of an infinite amount and endless source of labour in the preparation of the soil, tending the seedlings, transplanting, weeding, worming, watering, hocing, plucking off suckers, dead leaves 
18 TOBACCO GROWING IN GREAT BRITAIN.

and tufts, protecting from cold, gathering the leaves as they ripen, wilting, drying, and curing, -a programme of work which may well fill the philanthropic landowner with renewed hopes for the future of his tenants and dependants, while securing to himself the advantages naïvely described in the following words by a local authority, as accruing to Blandain: "Cette eulture a fait jusqu' aujourd'hui la fortune de Blandain, et Iui permit de traverser fièrement la clise agricole. Je suis même tout porté à croire qu'elle ne fera qu' augmenter si on a le bun esprit de s'inspirer un peu plus de la science, ce qui manque encore à nos planteurs du cru."

But beyond this let it be remembered by the "food supply" objectors that, whereas the acreage under wheat alone, up to 1884, in the United Kingdom was 2,749,470, only 40,000 acres (producing $40,000,000 \mathrm{lbs}$. of tobaceo at the rate of 1000 lbs. per acre) will suffice to yield enough shag or common roll to supply the entire home consumption, leaving seant room for fear that the cultivation of tobacco will interfere in any appreciable degree with the cultivation of corn.

In answer to the universally quoted objection of climate, let us glance at some of the eountries where tobaceo flourishes, and learn from the statisties furnished by the Customs returns what 
is the amount exported to England from the same.

In America tobacco forms a part or the sole trade of twenty-one States, extending from Florida to Canada, and certainly including climates far colder than our own; even in Virginia, the ice being frequently thick enough on ponds for the supply of ice-houses.

From the United States in 1884 we imported $37,186,980$ lbs. of unmanufactured tobacco, or $£ 1,183,102$ worth. From British North America in the same year $150,056 \mathrm{lbs}$. or $£ 5188$ worth. To turn to Europe.

Tobacco-growing in Hungary has become a leading feature, involving the employment of a staff of Government officials for the express superintendence of the trade. As regards the growth and cure of tobacco in Austro-Hungary, Herr Mandis, Government Inspector, has written a valuable work well worth the perusal of intending growers at home.

"Mr. Mandis," says Forbes Watson, in his Report on Tobacco-Growing in India (1871), "speaks from a long personal acquaintance with and experience of the cultivation of tobacco in Holland, and in the various provinces of Anstria, where tobacco is grown extensively, about 160,000 acres being devoted to the pur- 
pose, and yielding a yearly crop of about 40,000 tons!" The Hungarian tobacco is finely flaroured and much imported into this country. The statistics report $1,464,350$ lbs., or $£ 57,43.5$ worth of tobacco from Germany.

There are large fields on the Rhine where the authorities have much encouraged the growth, as cultivated by small proprietors, giving employment to thousands of persons. Germany cxports largely to all countries, even, we are told, in bad seasons, to Havana.

In France the tobacco trade has of late years risen to great importance. As in Germany and Austria, the cultivation is a Government monopoly, and to the action of the Government is principally due the immense and rapid progress of the trade, for instance, as regards the choice of seed to be grown-a subject of primary importance. "Formerly in France each cultivator of tobacco provided his own seed; now the Government Administration has taken the matter into its hands and grows its own seed, selecting with extreme care only the finest plants for it, and this seed it supplies to the farmers, who are prohibited from using any other." From France, in 1884 , we imported 733,207 lbs. at a value of $£ 23,975$.

From Holland, where the tobacco cultivation 
has reached a ligh state of perfection, we imported in the same year $5,728,744 \mathrm{lbs}$. = $£ 246,795$. From Belgium, 299,863 lbs. = $£ 10,994$.

It may here be remarked, that in these Continental countries the tobacco of inferior quality is manufactured into cigars; there is a prestige attaching to cigar smoking, and the lower classes readily purchase these cheap articles in preference to shag. Continental tobacco is naturally imported by us in an unmanufactured state, in consequence of the enormously increased duty on the manufactured article (amounting to $5 s$. 6d. per lb. for cigars); but the growth of this country, should it never attain to the flavour and aroma of Havana tobacco, would, in the shape of cigars, be considered a luxury by the lower classes. Cases have occurred of persons making large profits by selling cabbage or tea-leaf cigars as tobacco -it is only fair to infer that inferior tobacco cigars would prove an equal bait to an admiring public!

In consideration of all this importation of Continental tobacco, it camnot well be upheld " that no Englishman would smoke (for instance) German tobacco;" if no Englishman would smoke it, what do we do with it all? and if 
this tobacco does find a ready market in England-in spite of the heary duty which renders it an expensive article-our own growth would bo equally saleable in point of flarour, and mueh more saleablo in regard of redueed priec!

Such being the positive facts-countries far colder than England and Ireland, to wit, Holland with its yearly frozen canals, Anstria with its piereing winds, and Germany with its interminable winters-if these enn produce tobacco and make a lively trade by exporting it, why, it may well be asked, should England, with her sea-tempered elimate and her boast of national freedom, be debarred from trying her chances against the rest of the world? or is she alone too ill-faroured by nature, too oppressed by Government, or, perhaps, too prosperous in her commercial enterprises, to be allowed her renture in the market?

What is it we ask for but freedom of eropping, - the chance given us, if one crop fails, of trying another?

Oul very ports, except those approved by the Commissioners of Customs, are closed to the reception of the tobacco grown in the countries whither our gold is sent to enable their Governments to pay their labourers and apply the newest inrentions of science! Do these 
measures sound like freedom, or are we reminded rather of despotic Russia and the antediluvian exclusiveness of Celestial China? The fact of any Government taking the initiative in a step so wise, and founded so distinctly on the laws of freedom, as that of making trade unrestricted, could not but gain the lasting sympathies of the people, and especially of those classes which would so materially benefit by the change, and benefit in a manner which a superficial glance may fail to detect, i.e. in the reduction of his (the poor man's) enormously disproportionate share in taxation. But tro have not space to enter into this matter.

As the Navigation Acts, the Corn Laws, and other's, have been altered or abolished to suit the times and the march of civilisation, so the Acts of Charles II., George III., and William IV., prohibiting the growth of tobacco in this country, should be modified to meet the urgent necessity of the present time.

It will be a proud moment for England and Ireland when our drooping agriculturists can lift np their "hands" of home-cured tobacco, with the triumphant sensation that once more the wealth which has leaked and flowed out into foreign lands is at last eddying and circulating 
in the mother country, filling her veins with the bright fluid of prosperity, and infusing fresh life thronghout her entire system.

This part of the subject cannot better be concluded than by giving an extract from $\mathrm{Mr}^{\mathrm{r}}$. Brodigan's dedication of his book to His Most Gracious Majesty (William IV.), and by commending its spirit, and the object therein petitioned for, to those who are at present in power in the land, and likely to influence the Government to look attentively and fairly into a question of so much importance, involving, as it does, the well-being of millions, and, perhaps, of the Empire itself :

"... Under the gracious and paternal auspices of your Majesty we hope to witness a most beneficial amelioration in an abandonment of the restrictive system so long preserved with respect to the growth of tobacco in these countries, and in a concession to the people of the free exercise of their industry in the culti. vation of their native soil. An amelioration so benevolent, and so advantageous to the best interests of the United Kingdom, cannot fail to give your Majesty new and lasting claims upon the affections of your subjects.

"To Ireland, whose welfare has been an ear!y 
object of your Majesty's solicitude, this alteration of British policy will present the most important advantages," etc.

And now we may proceed to inquire into the nature of the plant and the best method of its cultivation, and further show what is recorded in history of tobacco-growing in the British Isles.

II.

HOW IT SHOULD BE GROWN.

ToBAcco, of which there are several species belonging to the genus Nicotiana, is named after Jean Nicot, a Portuguese ambassador, who introduced it into France in 1560.

The plant belongs to the order Solanaces, or Nightshades, a dangerous family, including among its members the deadly nightshade, belladonna, henbane, thorn-apple or stramonium, and also the potato and tomato, all of which plants possess in a greatcr or less degree narcotic properties.

Nicotine, which is the active principle in tobacco, is a poison when taken in an isolated form, but when consumed in tobaceo is harmless to health except when used to excrss, in which 
case it causes a tendency to paralysis. The plant is an annual, varying in height from two to sixteen feet; it is in appearance something like a sunflower, in its earlier stages; it has a strong straight stem, with from four to sixteen large light-green leaves; the flnwer grows on the top of the stem in a cluster, and is succeeded by the capsules, oval-shaped, with a pointed apex, and each containing about one thousand . seeds.

The kind which is in most general use in America is the Nicotiana Tabacum, the common Virginian or sweet-scented tobacco; in Europe the Nicotiana Major or $\mathrm{N}$. Rustica is chiefly grown.

The American Encyclopædia remarks of tobacco:- "In England it is raised in gardens, and there is no question but it wonld be an important crop if it were not for the serere restrictions imposed upon its growth for manu. facturing purposes. It has been even grown in Scotland."

The date of the first introduction of tobacco into England is not quite certain, but probably the travellers Amidas and Barlow first brought it over in 1584 .

Smoking and snuffing quickly became the rage, the practice spreading like wildfire, and 
even ladies indulging in the new lnxury. Sir Walter Raleigh was not slow, it is said, in setting the fashion of smoking parties, at which entertainments his guests were regaled with pipes and spiced ale. Queen Elizabeth appears to have liked and encouraged the practice of smoking, and so long as she ruled the land the days of tobacco were days of peace.

In the succeeding reign, however, tobacco began to be decried by the physicians, and was intolerantly hated by the king, who, in 1604, added to the original daty of $2 d$. on the ponnd a further exorbitant charge of $6 s, 8 d$.

By this time the cultivation of tobacco had already begun in England, and, in spite of the opposition of the Crown, was pursued with success.

Cromwell, in his turn, thought fit to discourage the practice, and sent bodies of horse through the plantations to destroy them.

In the reign of Charles II. the first law was passed to restrain the still increasing caltivation of tobacco.

The Statute 12 Car. II. c. 34, an Act for prohibiting the planting, setting, or sowing of tobacco in England or Ireland, runs as follows: "Your Majesty's loyal and obedient subjects, the Lords and Commons in this present Parlia- 
ment assembled, considering of how great concern and importanee it is that the Colonies and plantations of this kingdom in Anerica be defended, protected, maintained, and kept up, and that all due and possible encomragement be given unto them; and that not only in regard great and considerable dominions and conntries have been latterly gained and added to the Imperial Crown of this Realm, but for that the strength and welfare of this kingdom do very much depend upon them, in regard to the employment of a very considerable part of its shipping and seamen, and of the vent of very great quantities of its native commodities and manufactures, and also of its supply with several considerable commodities which it was wont formerly to have only from foreigners, and at far dearer rates; and forasmuch as tobaceo is one of the main products of several of those plantations, and upon which their welfare and subsistence and the navigation of this kingdom and vent of its commodities thither do much depend; and in regard it is found, by experience, that the tobaceo planted in these parts is not so good and wholesome for the takers thereof, and that by the planting thereof your Majesty is deprived of a considerable portion of rone revenue arising by (Customs upon imported 
tobacco; do most humbly pray that it may be enacted by your Majesty; and it is hereby enacted .... No person, after 1st January, 1660 , to set or plant, improve or grow, make or cure, any tobacco in England, Wales, Guernsey, Jersey, Berwick-upon-Tweed, or Ireland. Penalty, forfeiture of tobaceo and value thereof, or $40 \mathrm{~s}$. for every rod or pole planted.

"Direction to Sheriffs, Jnstices of the Peace, Mayors, Bailiffs, and Constables, to burn, pluck up, consume, and utterly destroy all tobacco so growing."

Three years later, the penalty of $40 \mathrm{~s}$. a rod having proved insufficient to deter the tobaccogrowers from continuing their lucrative trade, a fresh law was passed.

1663, 15 Car. II. c. 7, s. 18.—" And forasmuch as planting and making tobaceo within this Kingdom of England doth continue and encrease to the apparent loss of his said Majesty in his Customs, the discouragement of English plantations in those parts beyond the seas, and prejudice of this kingdom in general, nowithstanding ..... (above-mentioned Act). And forasmuch as it is found by experience that the reason why the said planting and making of tobaceo doth continue, is that the penalties preseribed and appointed by the Law arc so little, as have 
neither power or effect over the transgressors thereof :

"Penalty encreased to $£ 10$ for every rod or pole planted."

That tobacco continued to be extensively grown we know from several sources, notably from the following passage in the "Gloucestershire Hangman's Request," written in 1655. The author says:- "The very planting of tobacco hath proved the decay of my trade, for, since it hatl been planted in Gloucestershire, espucially at Winchcourt, my trade hath proved nothing worth. .... Then 'twas a merry world with me! for', indeed, before tobacco was there planted, thero being no kind of trade to employ men, and very small tillage, necessity compelled poor men to stand my friends, by stealing of sheep and other cattle, breaking of hedges, robbing of orchards, and what not."

In 1670 a third and still more stringent Act was decmed necessary for preventing tho cultivation of this crop (which, in spite of heavy penalties, still increased in importance), and for regulating the plantation trade. "Whereas the sowing, setting, planting, and curing of tobacco within divers parts of tho Kingdom of England doth continue and encrease to the apparent loss of his Majesty's Customs, and the disconrage- 
ment of his Majesty's plantations in America, and great prejudice of the trade and navigation of this realm, and the vent of its commodities thither, notwithstanding ...." (two aboverecited Acts) .. "and forasmuch as the remedies and provisions by those laws are found not large enough to obviate and prevent the planting thereof ...

" 2 . Justices of the Peace to command all constables, etc., to make return to them of what tobacco is planted, and npon whose land.

"4. Powers to officers, etc., to pull up and destroy all plants.

"5. Penalty, 5s. from officers, etc., for every rod left growing.

"15. To continue in force for nine years." (Continued by 5 Geo. I. c. 11.)

But tobacco continued to be growr surreptitiously even after this last Act-for example, in Yorkshire, in the valleys of Ryedale and York, we find instances of persons growing a considerable quantity. We give verbatim the description of the same, by a contemporary. (Agricultural Survey of Yorkshire, by Tuke. 1782.)

"This plant was muçh cultivated for a few years, prior to the year 1782, in the Vale of York, about Stillington and Sutton, and also in a less degree in Ryedale. 
"In this district (Ryedale) it did not excite the notice of legal authority. In the richer parts of the vale, where the greatest quantity was raised, it was cured and manufactured by a man who had formerly been employed upon tho tobacco plantations in America, and who not only enred it properly, but gave it the proper cut, and finally prepared it for the pipe.

"But in the Vale of York the cultivator's of it met with less favourable circumstances; their. tobacco was publicly burnt, and themselves severely fined and imprisoned. Penalties, it was said, were laid, to the amount of thirty thousand pounds. This was enough to put a stop to the illegal cultivation of tobacco . . . I I will . . just mention sueh cireumstanees respecting its cultivation in this neighbourhood as I collected in the antumn of 1782 . I had not the opportunity of secing the plants on the ground.

"The species was, probably, Nicotiana Rustica, the English tobaceo, so called from the cirenmstance of its being the first species cultivated in England.

"The sceds were procured at the sced-shops, and handed about from one eultivator to another.

"The seed-bed as rich and fine as possible.

"The time of sowing, as soon as the weather" 
became warm enough to make it. vegetate; perhaps in April.

"When the seedling plants were strong enough to bear removing, they were transplanted from the seed-bed to the patch on which they were intended to stand.

"In the practice of one, they were planted out in quincunx manner, a foot asunder: in that of another, in rows two feet apart and one foot asunder in the rows.

"In both cases they were carefully hoed and kept free from weeds during the summer.

"In autumn, when the flowers began to drop off, they were cut and dried in.the shade.

"When dry, the leaves were picked off and pressed down close in casks and other vessels.

"The spring of 1782 being late, the plants did not, upon weak soils, reach maturity before the frosts began to set in. Hence a rich forcing soil seems to be necessary to the culture of tobacco in this climate. The regetation, however, may be greatly forwarded by forcing the seedling plants in a hot bed, and transplanting them out as soon as the frosts of spring are over.

"Since that time, it does not appear that any attempts have been made at the cultivation of tobacco. The people, paying obedience to laws 
passed many ages since to encourage our tobacco plantations in America, have ceased to cultivate a plant to which our climate seems well adapted, and of which it might now be good policy to promote the cultivation, as we have long since lost the Colonies for the encouragement of which such rigorous laws were enacted, and which now stand on our books the instruments of persecution to the ignorant or unwary, and no longer of supposed public ntility."

In 1782, during the American war, Scotland, which had not been included in the restrictive Acts, commenced growing tobacco.

The Rev. R. Douglas gives the following account of the proceedings (Agricultural Survey of the Counties of Roxburgh and Selkirk, 1798): - "Tobaceo, during the American war, was cultivated to a considerable extent in the neighbourhood of Kelso and Jedburgh, and in somo other spots. Its produce was so great that thirteen acres at Crailing fetched $\mathscr{E} 104$ sterling, or $£ 8$ sterling per acre, at the low rate of $4 d$. per pound, and would have brought more than three times as much had not an $\Lambda$ et of Parliament (22 Geo. III. c. 73) obliged the cultivator to dispose of it to Government at that price. 'T'his country lost about $£ 1500$ sterling by that 
Act, which passed whilc the tobacco was growing; yet it excited not as much murmuring and clamour among the sufferers as have been elsewhere repeatedly raised, with less reason, against other Acts, in no respect so arbitrary and oppressive."

In 1782 the Act of Charles II. was extended to Scotland, a special Act in that year being passed for the purpose; including a clause, however, to permit the tobacco growth of Scotland to be removed to England, under certain restrictions and for a limited time.

By 19 Geo. III. c. 35, the prohibitive Acts of Charles were repealed as to Ireland, but the Irish were not then in a fit state for taking up a great new trade, especially as a concession from England, and placed under very disadvantageous restrictions.

Some years later, however, tobacco began to be cultivated, and Mr. Brodigan, among others, took the matter up, and wrote his treatise on the growing of tobacco in the British Isles.

In 1829 over one thousand acres wcre under cultivation in one county alone, five hundred hogsheads being sent at one time to Liverpool for exportation. 
The climate and soil proved perfectly adapted to the requisites of the plant, and the trade was beginning to flourish and bring in promising receipts when rumours were heard that the Government projected extending the prohibitive laws to Ireland.

Mr. Brodigan immediately sent a petition to head-quarters on the subject, setting forth the advantages accruing to the country from the pursuit of so flourishing a branch of agriculture. He was answered by Mr. G. Dawson, M.P., from whose letter we give an extract :-

"The duty in the United Kingdom on this article, in 1829 , amounts to $£ 2,800,000$; you will allow, therefore, in our present financial condition, that every effort must be made to protect it. There are but two ways of effecting this object, either by prohibiting the growth, by which the laws in the three parts of the United Kingdom will be assimilated, or by imposing an excise duty on the home-grown article. The former mode has been preferred as the least liable to objection in practice, though I must allow it is in opposition to the principles which have lately been adoptcd with respect to trade." -Extract from letter to Mr. Brodigan from G. Dawson, Esq., M.P., Treasury, London. 
A Select Committee was appointed to inquire into the subject of tobacco growing in the United Kingdom, witnesses were called and examined, and the proposed permission finally rejected on several grounds, but chiefly on account of revenue difficulties.

In 1831 a final Act was passed ( 1 \& 2 Will. IV. c. 13) making the prohibitory laws applicable to Ireland as well as England and Scotland, and imposing a fine of $£ 100$ on all persons having in their possession more than one pound of tobacco the growth of the United Kingdom.

Thus a movement of the utmost importance was stifled, as many thought, without sufficient reason and without obtaining a public hearing.

A few remarks may now be offered on the choice of tobacco seed, with a short account of the method of growing and curing, as employed by persons in management of tobacco plantations in Europe and America.

The two principal species of tobacco are,-

1. The Nicotiana Tabacum, Virginian or sweetscented tobacco, a narrow-leaved species, much cultivated in Virginia, Cuba, and Brazil, and much esteemed for flavour. Of this the whiteflowered tobacco is a variety. It grows to the 
height of five feet, and produces a valuable crop.

2. Nicotiana Rustica Major or greater broadleaved; varieties of this species are much grown in Germany; it is a large and hardy plant, well suited to northern climes. It is more coarscly flavoured and less aromatic than the Virginian, but "by a skilful manufacture, and probably by mixing the tobacco of cold countries with that of hot countries, by using different species, and, perhaps, by selecting particular varieties of the different species, the defects in flavour arising from climate" hare been, in Holland and other" places, to a great extent overcome.

With tobacco, as with every other product, the grand secret of success (in the first instance) is to find the right kind of seed for the soil, and this can only be done by careful experiments.

The method of supplying good seed to the farmers in France has already been mentioned. "Before the Government took the matter up," says Forbes Watson, "the seed was almost always a mixture, so that the plants were very often of undesirable crossings, and did not xipen at the same time."

"The best means for obtaining practical knowledge and for trying scientific experiments is to 
be accomplished by means of farms under the charge of practical agriculturists, who can give the subject the full care it requires." As, for instance, in India, where we are told by the same authority that the Madras Government has "sanctioned the suggestion of the Board of Revenue, to the effect that the experimental cultivation of tobacco should be at once commenced under Mr. Robertson, Superintendent of the Government Farms, and that the results should be snbmitted to Mr. Broughton for analysis." We may conclude that the Government would be equally able and willing to employ similar beneficent measures at home. Indeed our Royal Agricultural Society would soon supply the agricultural and scientific knowledge needed for the purpose in this country.

The experimenters on tobacco should be placed under the supervision of the Royal Agricultural Society, and the experiments carried on in the same way as those on potatocs in 1884. The committee offered prizes, and employed every means, both at home and abroad, for the discovery of the cause, origin, and prevention of the potato discase. Mr. Carruthers, in his "Report" on the subject in the same jear, wrote as follows: "The Committee fixed on 
twenty localities in which to grow these experimental potatoes, selecting them in the districts where potatoes are extensively cultivated. . . . . . The hearty co-operation of the following gentlemen, practically interested in the culture of the potato in these rarious distriets, was obtained." Here follows a list of the gentlemen who undertook to grow a hundredweight of each kind of competing potato. The growers were giveri full instructions how to act, and were required to furnish full particulars as to soil, position, drainage, amount grown, manures, etc. Mr. Carruther's himself undertook to inspect the plots while the potatoes were growing, and he, with the further assistance of five gentlemen, visited the localities, superintended the raising of the crops, ete., and subsequently published his Report, which was based on the information furnished by the growers and on his own careful observations.

Such a system employed on behalf of tobaceo would ensure success without the waste of time, money, and land, to which independent and totally ignorant growers would be liable.

A rich, loamy, and rather loose or sandy soil is the lest adapted for the tobaceo plant; but, whererer potatoes or turnips flourisl, tobaceo 
would be likely to thrive. A soil which in dry weather becomes thickly caked, and swampy after heavy rains, is unsuitable; the preparation of such soil would probably be rery expensive, as the ground must be carefully broken and tilled, and rendered very fine for tobacco growing.

A country likely to be flooded would be fatal to tobacco, as twenty-four hours under a flood would destroy the crops.

Likewise a northern exposure, subject to very cold winds, or any land much above the level of the sea, or a strong loam incumbent on clay, is not suitable.

The best plantations are those lying on the south side of gentle slopes, or places protected by woods and shrubberies; the land which produces mostly oaks, hickory, and other deciduous trees, is generally the most favourable.

" The character of the soil," says Herr Mandis, "that is, the mixture of its ingredients, exercises an important influence on the growth of the tobacco plant, and on the quality of its produce."

It is a well-known fact that the best tobacco is not the strongest; on the contrary, fine tobacco contains less nicotine than the coarse kinds, but is distinguished by its richness of aroma. 
Forbes Watson says: "Nicotine is the aetive principle of the tobaceo which eonstitutes its strength. Its amount has been varionsly estimated in different varieties. Schlössing found in a French tobacco 3.8 per cent.-onee, 9 per cent. ; in Kentucky, 6 per cent. ; in Virginia, 6.8 per eent. ; and, in Havannah, not quite 2 per eent. A fertile heavy soil, strong manure, and abundance of moisture, are the conditions which facilitate its formation. Besides, tho amount varies very much with the period of gathering the leaves; it inereases as the leaves become ripe."

Mr. Faunce de Laune remarks about this matter, that the sooner the leaves are picked the less exhausting is the plant to the soil, and the less of the objectionable nicotine will be dereloped.

As the character of the soil, an all-important point, depends greatly on the manuring process, we would say a few words on this subject.

In the first place, the manure should on no account be used fresh, but in a tolerable state of decomposition, and always put in in the autumn or winter months, or early spring, that it nay get throughly ineorporated with the soil before planting-time. 
Guano used alone is destructive; an instance is recorded of the produce of a whole season being refused for purchase on account of the strong taint produced by this form of manuring.

Green manuring, liquid manure, poultry-yard scrapings, and ashes are very valuable; the fields are sometimes spread with branches of trees in the autumn, which are burnt on the spot, and the ashes left to mingle with the soil; roadscrapings, town manure, lime, gypsum, and compost manure-all these are in different ways beneficial to the tobacco plant-but every dressing which does not become finely incorporated with the soil is destructive, producing mould and other ill effects.

The land must be deeply ploughed in autumn, and the manure, if fresh, put in then. Before setting the plants, the land must be finally ploughed deeply and evenly, and carefully smoothed and harrowed.

"When tobacco is planted on the three years" system of rotation," says Herr Mandis, speaking of tobacco as a rotation crop, " it is best to set it in fresh manured fallow ground, this crop to be succeeded by a winter one, as wheat or rye, and in the third year by a summer one, as barley, oats, etc. The fallow ground, howerer', should 
always be manured; but in Lower Hungary, where the soil is mostly very rich, this need seareely be done oftener than once in six or nine years. It is therefore attempted to improve the soil by means of hoeing plants, and the following rotation is obserred: Ist, Hoeing plants, maize, tobaeeo; 2nd, Wheat; 3rd, Fodder plants; and afterwards stubble pasture and summer fallow."

He then gives instanees of rotation crops, followed in Lower Hungary :

(1) 1. Fodder plants in manure.

2. Tobacco.

3. Wheat.

4. Summer pasture with elover.

5. Clover.

6. Winter erop.

(2) 1. Tobaceo in manure.

2. Wheat.

3. Summer erop, such as barley. with clover.

4. Rape.

5. Winter crop.

6. Oats.

It is a fact for which we are further indebted to Herr Mandis. that the tobaceo crop "exhansts 
principally the potash, lime, and magnesia in the soil, while the phosphoric, sulphuric, and silicic acids will go on increasing in amount. If now a crop of grain be taken from the same soil these acids will be used up, whilst potash and lime will be accumulated, thus restoring to the soil the conditions for growing tobacco."

Sowing the seed: Having obtained a seed suitable to the soil, it must be sown during the months of March and April, in sheltered beds of fine mould-or, far better, in hotbeds, covered over during frosts and at night, either with mats supported over sticks or boards, or with varnished calico or glass.

These coverings must gradually be left off until the plant is hardy and the weather warm.

The seed should be well mixed with clear woodashes; a tablespoonful of seed will sow ten or eleven yards square, or, according to Mandis, the following proportions may be used: Of fresh seed, to set one acre, in cold beds, 1 to $3 \frac{1}{3} \mathrm{oz}$. -according if it be large or small tobacco; in warm open beds $\frac{3}{4}$ to $2 \mathrm{oz}$. - in hot beds $\frac{1}{2}$ to $1 \frac{5}{6}$ oz. Of old seed rather. more must be used.

From $1 \mathrm{oz}$. to $1 \frac{1}{2} \mathrm{oz}$. will plant one acre.

The seed must be pressed gently into the level of the earth, which must have been well manured 
with mouldy dressing. The pressing is generally done by the feet, with heelless shoes; or, in preference, the seed, when scattered, may be lightly corered with fine garden-mould or rotten manure, scattered with a sieve, not deeper than half an inch. The seed ought to be sown so that four plants grow to a square inch; it will germinate in from four to eight days. The plants come up like cabbages, sown broadcast, and require plenty of soft water, slightly warmed.

The seedlings must be thinned as occasion requires, and the ones pulled up he transplanted into a sheltered nook of the garden, and kept, for replenishing the plantation.

The seedlings, having been gradually and perfeetly hardened, must be removed into the plantation not later than the 15th June, or from four to eight weeks after sowing, the field being already prepared for their reception in rows of well-manured hillocks flattened at the top, where a hole is bored and a young plant carefully placed in each,-or simple furrows may suffice, only care being taken to plant at equal distances, giving eaeh plant from one to three fect square of ground, according to tho size of the rariety grown.

The further cultivation of the plant is much 
the same as for turnips, only requiring a great amount of extra care and attention. The ground cannot be too carefully hoed and weeded, and a systematic hunt for caterpillars and other insects must be kept up. For this purpose flocks of turkeys are frequently turned into the plantation to thrive on the insects which would otherwise destroy the plant.

The effects of frosts may be warded off by protecting the plants with grass and branches, and smoky fires may be lit on the edge of the field whence the wind blows. All such precautions are fully repaid by the value of the crop which they preserve from harm.

The growing plants should be kept very clean, all dead or soiled lower leaves carefully taken off, as also all suckers.

When the sprout, or beginning of the flower, appears at the top of the stem, it must be pinched off; this topping of the plant prevents it attaining more than a moderate height (from two to three and a half feet), and keeps all the strength of the sap in the leaves.

A few plants may be allowed to flower for the sake of the seed.

In September the leaves are ripe, and when 
they assume a yellow tinge and look knotehy and brittle they are fit for gathering.

In tropical climates the whole plant is cut down; but in more northern plantations the ripening does not take place altogether, so each leaf, as it ripens, is picked; thus the picking may last over several weeks.

On the Continent the leaves are divided into three classes : the lower leaves or sandgut, which ripen earliest, are first picked, then the middle leares or erdgut, and lastly the topmost leares, or bestgut.

After the picking comes the curing process, and this is the most important part of the operations.

Herr Mandis says, about this part of the business :- " The plant may have prospered perfectly, and still, by a faulty method of drying, it may become practically worthless."

This fact is illustrated by the tobaceo of the Cape of Good Hope, where the curing is done in an antiquated or slorenly manner, tho tobacco, in consequence, being so nauseous, that the effects on a newcomer are disastrous. The habitués, however, of this preparation prefer it to any other, and declare it to be perfectly wholesome. Such is the force of habit! 
After lying in the field for a day to wilt or wither, the leaves, having been arranged in small neat heaps on the ground, must be removed to a well-ventilated covered place or drying-honse; this may either be a shed built on purpose or a cottage kitchen, but the hopoasts, which already exist in our hopping districts, would serve admirably; any barn, properly ventilated, could be used for the purpose.

There are different methods of curing the leaves. In some places the sweating process is assisted by means of open fires on the floor; in others steam is used; the conntry-folk in Germany dry their tobacco simply by hanging it under the eaves of their cottages. In Belginm, where the cultivation of tobacco is carried on by small householders, the proprietor's whole family is employed in the work of cultivating and curing. The picking is performed by adults, while the children, seated on the ground, string the leaves singly, which are then hung up like illumination lamps, to be cured under thatched sheds and in the open air.

Herr Mandis gives a graphic description of the inexpensive and apparently satisfactory method in use in Hungary. 
The leares are strung up singly in the dryinghouse, and by constant change in their relative positions-sometimes being crowded together, sometimes the air having free access through their midst, sometimes exposed on sun-framesthe process is successfully performed, and a sound, aromatic, and finely-eoloured tobacco produced, and finally made up into "hands" or neat bundles of leaves dexterously rolled and tied together, preparatory to packing.

The different processes of curing are placed in the following order by Herr Mandis :-

1st. Wilting or withering the leaves.

2nd. Stringing up on strings or sticks.

3rd. Left in "close suspension," to get the right colour.

4th. Hung in the sun.

5th. Drying.

6th. Sweating.

It will have been observed, from this slight sketcl, that the cultivation of tobaceo requires no great outlay and no paraphernalia of any kind; plenty of manual labour, carcful industry, and intelligent thrift are the chief requisites; and, if we fail, we shall fail from a lack of 
these qualities and not from lack of capital or want of sun.

In conclusion, we would strongly urge the importance of this movement of tobacco growing in the United Kingdom on the attention of all who are interested in our agricultural welfare.

Surely there is enough of the old English spirit left in us to will and to do something for our own relief! Surely we are not content to utter the modern cry for emigration - that fashionable and gilded way out of all difficulties -and placidly to sit down and see England's best sons turning their energies and their capital into foreign countries, while there is a chance of retaining those energies and that capital at home and of turning them to as good account as in the roughness of exile!

Should we not rather unite in a manly effort to ameliorate our condition?

It is difficult to conceive how, as long as thero remains a chance of success, any stone can be left unturned.

All honour to those men who, in the face of public opinion, and in spite of difficulty and novelty, set their minds to becomo acquainted with and overcome the obstacles to any important project. 
Never since tho world began has a new scheme obtained public recognition without first incurring ridicule, opposition, and abuse. The present proposal will not bo exempt from such drags, and it is well that it should be so; the wheels of progress must needs be kept back that all questions may be fairly discussed, and the right method decided on, before we ignorantly rush into the valley of plenty below.

That we are sorely in need of some such step as the introduction of a new industry no one will deny; let some other suggestion, equally practicable, equally hopeful, equally lucrative, be proposed, and we will weleome it. In the meantime we remain convinced, and with us many men of importance in the political and agricultural world, and many thousands of farmers and labourers who have already winded the quarry, that the revival of tobaceo growing may still become a powerful means of ameliorating the financial position of agriculture throughout the United Kingdom.

It was with great interest we listened to the debate on the subject of tobaceo growing when Lord Harris introduced the subject in the House of Lorils on the 30th of Mareh. His proposal that a limited number of acres should be deroted 
to the purpose of experiments was passed, and may prove, we trust, but the stepping-stone to a wide-spread cultivation of the plant.

A. A. Erskine.

I wish to express my sincere thanks for the kind and valuable assistance afforded me by Mr. Carruthers, of the British Museum, F.R.S., Mr. Faunce de Laune, of Sharsted Court, and Mr. W. Leigh Pemberton, barrister-at-law. 
The following letters will prove interesting, as throwing further light on the subject :-

Letter from $\mathbf{M r}$. Brotherston.

Shedden Park Road, Kelso,

15th Mareh, 1886.

Dear Sir,

* $\quad * \quad * \quad * \quad * \quad *$

The following is from the new Statistical Act of Roxburghshire, written in August, 1835 (p. 178) :-

In the former statistical account, a proof of the firmness of the soil and mildness of climate is furnished which is worth preserving. It appears that about that time (40 years ago) an attempt was made to cultivate tobacco in Scotland. .... In one season a tenant in this district drew $£ 115$ for tobacco plants, and afterwards raised a crop on 12 or 13 acres, which he sold upon the ground for $£ 320$; but, an Act of Parliament intervening, the purchascr was unable to fulfil his bargain, and the farmer was compelled to dispose of his tobaceo to Government at only $4 d$. per pound, at which rate it brought him only $£ 10.1$. 
It was also grown largely in fields a little to the east of Kelso, part of which is now a cemetery. A road at the west end of the cemetery is still called the "Drying-house Lane," from the fact that the house where the tobacco was dried stood there.

Between 20 and 30 years ago I used to grow as much in a garden at Ednam as kept me smoking. The variety I liked best was Nicotiana Virginica; I have had them as much as eight feet high and leaves nearly three feet in length, but you could not expect that size in a field. The soil was trenched three feet deep and heavily manured. For this district the young plants require to be raised in a hotbed, and planted out about the end of May. The greatest enemies the young plants had to contend with were the slugs.

Yours faitbfully,

(Signed) A. Brotherstox. 
Letter from $M r$. Brotherston.

Dear Sir,

Shedden Park Road.

You ask how I dried the tobacco? To begin while still growing. As soon as the flowers appeared I pinehed them out, and also the lateral shoots, which gave the large leaves tho full benefit.

The lower leaves began to get yellowish first; these were picked off and hung in an airy place to dry. In dull autumns they never got this yellow tinge. In that case I took the whole plant and hung it top downwards. After they were thoroughly dry I took advantage of a damp day to pack the leaves close together, so that they might get slightly heated, after which they were redried. When preparing the leaves for uso I sprinkled a little water on them, and, when moist and flaceid, cut out the midribs and packed them in a metal box (rather larger than a cake of cavendish), and pressed it in a viec. I found that the longer and heavicr it was pressed it got the blacker; when lightly pressed it was brown. I grew something under 100 plants, which was within tho limit allowed by law. The excisemen told me I could grow as much as I pleased for my own use, but not for sale. 
I believe the Nicot. Rustica would be the sort to grow here; it does not grow so large, nor is it so fine as the Vir., but it is hardier. I have no doubt that tobacco could be perfectly grown on many parts of these uplands, and especially the South of England and in Ireland.

Yours faithfully,

(Signed) A. Brotherston.

Translation of a Letter from a Flemish Farmer.

12th March, 1886.

* * * * * *

The best soil for the cultivation of tobacco is a dark rich peaty, and not too stiff soil, in a sheltered situation; light-coloured soils (des terres blanches), and an open unprotected country, never suit, several trials having been made at different times, but always without success.

The cultivation of tobacco demands manual labour, and, above all, a great deal of manure; but after the manure is put in four or five crops of cereals can be taken, with scarcely any addi- 
tional dressing. We generally sow the tobaccoseed in the open air as soon as the fine weather comes. It would, however, be preferable to use hot-beds, to mature the plants earlier, so as to harvest, and, above all, cure before the rains, which usually set in towards the end of September or the beginning of October. These plants, arrived at a certain age, are transplanted during the first days of June, and even later if the plants are not very successful.

During its growth, the plant requires much attention; it must be freed of its spronts so as to permit the growth only of a certain number of leaves. The gathering takes place in September, and is performed by adults. Children are placed in the field and thread the leaves singly, which are then hung up like illumination lamps, to be cured under thatched sheds and in the open air.

The tobacco, when dried, is deposited in barns till delivered over to the merchant or the factor.

The cost and the rate of production of the plant are as follows (for one hectare, $\mathrm{Ol}^{*}$ 2A. 1R. 35P.) :- 
Francs. $\quad £$

1. Varions manures . . $1000=40$

2. Labonr (approximately) $\cdot 1000=40$

3. Government Tax, two centimes

the plant, about 40,000

plants per bectare . $\quad 800=32$

4. Rent, taxes and rates, etc. $\quad 300=12$

$$
\text { Fr. } \overline{3100}=\overline{2124}
$$

I was forgetting to tell you that the fiscal duty of two centimes per plant is not levied on useless plants.

An ordinary year readily yields a produce of 3000 kilogrammes ( 1 kilo $=2 \mathrm{lbs}$. $3 \frac{1}{4} \mathrm{oz}$.) of tobacco to the hectare $(1$ hectare $=2 \mathrm{~A} .1 \mathrm{R}$. 35P. $)$, of which 70 per cent. is of first quality, and 30 per cent. of second and third quality; these inferior qualities sell at 20 per cent. less; the first quality is selling. at present, at 1 franc 50 centimes the kilogramme, or for 2000 kilos

2nd and 3rd qualities, selling at

Ifr., 900 kilos. . . . 1080 3150 francs. 
having taken into account the different erops which are taken afterwards without extra manure, as I told you before.

Only it requires a starting eapital of from 500 to 700 franes per hectare for setting up the shelters, which consist of thatched open sheds, and for pine rods, which however last for $\mathrm{np-}$ wards of twenty years.

The cultivation is principally carried on by small householders, whose whole families are thus occupied, but I have good reason for believing that, if earried on on a large scale, the expenses would be greatly reduced, and especially in manure, which the small cultivators eannot use in sufficient quantities to enable them to procure it at wholesale prices.

The industry has, up to the present time, made the fortune of Blandain (frontier town), and has cnabled it prondly to tide over the agrieultural crisis; and I am persuaded that it will go on increasing if we have the good sense to become a little better acquainted with the science, of which our planters are still very ignorant.

Westmunster: Printed by Nichols and Son3. 25, Parliament Street. 


SB

278

G7E7

Erskine, A

A

Tobacco growing in G? Britain and Ireland

Eiological

\& Medical

\section{PLEASE DO NOT REMOVE \\ CARDS OR SLIPS FROM THIS POCKE}

\section{UNIVERSITY OF TORONTO LIBRARY}




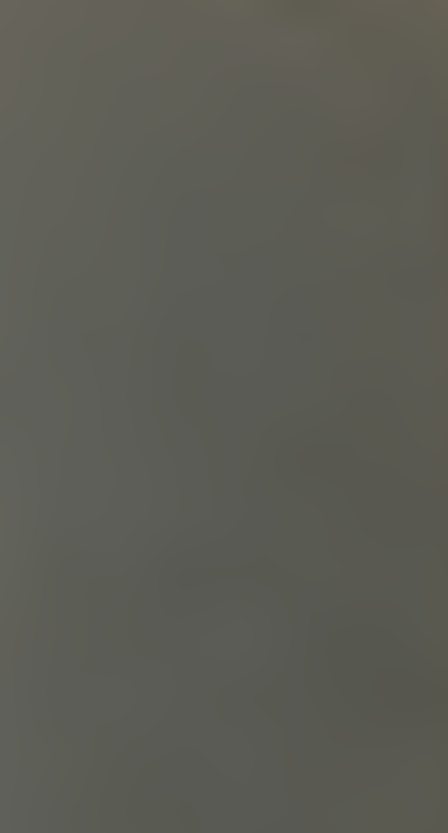

